\title{
Paulina Jęczmionka
}

Uniwersytet im. Adama Mickiewicza w Poznaniu

"Gazeta Wyborcza” $i$ „Rzeczpospolita” wobec wyroku Trybunału Konstytucyjnego $z$ dnia 11 maja 2007 r. w sprawie ustawy lustracyjnej (analiza porównawcza)

\section{WPROWADZENIE}

Celem artykuŁu jest ukazanie problemu prezentowania lustracji w dyskursie prasowym na przykładzie „Gazety Wyborczej” (dalej: GW) i „Rzeczpospolitej” (dalej: Rz). Artykuł jest także próbą ukazania opozycyjności obu gazet względem siebie w zakresie tematu lustracji, dotyczącej jej ustawy i wyroku Trybunału Konstytucyjnego (dalej: TK) $\mathrm{z}$ dnia 11 maja $2007 \mathrm{r}$.

Należy zapytać, czy autorzy zamieszczanych w GW i Rz publikacji podobnie komentowali wyrok TK z 11 maja 2007 r. w sprawie ustawy lustracyjnej i dlaczego komentowali wyrok w taki, a nie inny sposób. Odpowiedzi na te pytania pozwolą bowiem stwierdzić, jakie stanowisko w sprawie lustracji i wyroku TK wyłania się z publikowanych przez obie gazety treści oraz rozstrzygnąć, czy były one stronnicze. Dzięki temu możliwą stanie się ocena, jak ważne dla obu redakcji są wyznawane przez ich dziennikarzy poglądy polityczne i w jaki sposób autorzy starają się ich bronić.

Przystępując do badania przyjęto hipotezę, że zamieszczone na łamach GW i Rz treści komentowały wyrok TK w sposób odmienny, prezentując zupełnie inne stanowisko wobec lustracji. Powodem miało być przyjmowanie przez redakcje opozycyjnych względem siebie linii programowych.

- W celu przeprowadzenia analizy i sprawdzenia, czy postawiona hipoteza jest słuszna, zadano 5 pytań badawczych. W trakcie badania pytano:

- Jakie poglądy na lustrację zaprezentowali autorzy publikacji na łamach obu gazet?

- Jakimi argumentami posługiwali się w ocenie lustracji?

- Jakie stanowisko wobec ustawy lustracyjnej zajęli? 
- Do czyich poglądów i opinii (osób, partii politycznych) odwoływali się najczęściej?

- Jakie stanowisko zajęli wobec wyroku TK?

\section{LUSTRACJA JAKO ZAGADNIENIE POLITYCZNE}

TERMIN „LUSTRACJA” pochodzi od łacińskiego słowa lustrum, które w religii rzymskiej oznaczało składaną przez cenzora po każdym cenzusie oczyszczającą ofiarę za cały naród ${ }^{1}$. W Polsce pierwotnie termin ten oznaczał opis dóbr królewskich sporządzany w latach 1564-1789 przez specjalne komisje ${ }^{2}$. Współczesne znaczenie tego słowa zostało najprawdopodobniej zapożyczone z języka czeskiego (lustrace), gdyż Czechosłowacja była pierwszym państwem, w którym słowa „lustracja” użyto odnośnie działań prawnych i politycznych zmierzających do ujawnienia agentów komunistycznych służb specjalnych. O ile jednak w Republice Czeskiej mianem lustrace określa się zakaz pełnienia określonych funkcji przez byłych funkcjonariuszy komunistycznej partii i policji politycznej, o tyle w Polsce lustracja odnosi się do ujawnienia faktu służby, pracy bądź współpracy z tajnymi służbami państwa komunistycznego przez osoby pełniące lub kandydujące do ważnych funkcji publicznych ${ }^{3}$.

Temat lustracji jest obecny w polskim życiu politycznym od ponad 20 lat. Trudno jednak określić jednoznacznie moment, w którym rozpoczęła się dyskusja. Według wielu autorów, a przede wszystkim przeciwników premiera Tadeusza Mazowieckiego, to on jako pierwszy poruszył problem lustracji. O stosunku nowego rządu do rozliczeń z przeszłością miało świadczyć exposé sejmowe z września 1989 r. Premier zadeklarował wtedy politykę tzw. „grubej kreski”4. Krytycy T. Mazowieckiego uważają, że była to deklaracja odpuszczenia win komunistom ${ }^{5}$.

${ }^{1}$ P. Grzelak, Wojna o lustrację, Warszawa 2005, s. 7, za: Nowa Encyklopedia Powszechna PWN, Warszawa 1995, s. 828.

${ }^{2}$ Ibidem, s. 7.

${ }^{3}$ B. Banaszkiewicz, Rozrachunek z przeszłością komunistyczna $w$ polskim ustawodawstwie i orzecznictwie Trybunatu Konstytucyjnego, „Ius et Lex” 2003, nr 1, s. 474.

${ }^{4}$ T. Mazowiecki mówił wtedy: „Przeszłość oddzielamy grubą linią. Odpowiadać będziemy jedynie za to, co uczyniliśmy, by wydobyć Polskę z obecnego stanu”. J. Woleński, Lustracja jako zwierciadło, Kraków 2007, s. 37.

${ }^{5}$ Zdaniem historyka Antoniego Dudka, T. Mazowieckiemu chodziło przede wszystkim o odcięcie się od epoki rządów komunistycznych i podkreślenie faktu rozpoczęcia nowego okresu w historii. Jednak, w opinii A. Dudka, niezdolność rządu do zerwania z dziedzictwem PRL sprawiła, że przeciwnicy premiera zdefiniowali „grubą kreskę” 
Według Piotra Grzelaka, autora książki Wojna o lustrację, dyskusja na ten temat rozpoczęła się w mediach ${ }^{6}$, a w kwietniu $1990 \mathrm{r}$. problem poruszono z mównicy sejmowej. Wystąpił na niej poseł Roman Bartoszcze, który sugerowal, iż należałoby sprawdzić, kto z obecnych parlamentarzystów współpracował ze Służbami Bezpieczeństwa (dalej: SB). Później do problemu lustracji Sejm wracał wielokrotnie. Dyskusje nad nim prowadzono przy okazji każdej podejmowanej inicjatyw prawnej. Jednak, mimo upływu czasu, proces lustracyjny wciąż nie jest w Polsce zakończony.

\section{USTAWA Z 18 PAŹDZIERNIKA 2006 R.}

UstaWA, która stała się przyczyną medialnej dyskusji, będącej tematem artykułu, została zaprojektowana przez rząd Prawa i Sprawiedliwości (dalej: PiS). Sejm, po poprawkach Senatu, uchwalił ją 18 października 2006 r. Projekt poparły wszystkie kluby poselskie poza Sojuszem Lewicy Demokratycznej (dalej: SLD), którego posłowie złożyli do TK wniosek o sprawdzenie zgodności nowych przepisów z Konstytucją. Ustawa lustracyjna PiS wzbudziła wiele kontrowersji zarówno wśród polityków, jak i w mediach, bo w zasadniczy sposób zmieniała model lustracji w Polsce . Do najważniejszych zmian należało zlikwidowanie sądów lustracyjnych, urzędu Rzecznika Interesu Publicznego, instytucji pokrzywdzonego i możliwość autolustracji. Znacznie rozszerzono listę osób podlegających lustracji (ustawa wyliczyła 45 funkcji publicznych), dopisując do niej m.in. pracowników wyższych uczelni i dziennikarzy. Ogólne określenie organów bezpieczeństwa przyjęte w ustawie z 1997 r., zastąpiono 14 kategoriami, doliczając do nich organy państw obcych o zadaniach podobnych do zadań służb Polskiej Rzeczypospo-

jako tolerancję dla sił postkomunistycznych. Zob. A. Dudek, Historia polityczna Polski 1989-2005, Kraków 2007, s. 55.

${ }^{6}$ Historyk przywołal artykuły publikowane m.in. w GW, Rz i „Tygodniku Solidarność" w kwietniu 1990 r. Jego zdaniem, przyczynkiem do tych publikacji były wydarzenia w Niemczech. Tam bowiem ujawniono nazwiska niektórych przedstawicieli opozycji antykomunistycznej, zarzucając im współpracę ze Stasi - Ministerium für Staatssicherheit (Ministerstwo Bezpieczeństwa Państwowego). Polscy dziennikarze sugerowali, że także wśród polskiej elity znajdują się agenci SB. Zob. P. Grzelak, Wojna..., op. cit., s. 17-19.

${ }^{7} \mathrm{Już}$ sam tryb jej uchwalenia budził zastrzeżenia, ponieważ prezydencka nowelizacja została uchwalona zanim jeszcze pierwotna ustawa zaczęła obowiązywać (vacatio legis wynosiło 3 miesiące, a nowelę uchwalono 14 lutego 2007 r.). Ciekawe jest również to, że Sejm przyjął poprawkę, by nowelizacja weszła w życie w dniu, w którym TK miał na wniosek SLD zbadać ustawę z października. W tym momencie nie było to już możliwe, bo ustawa częściowo przestawała obowiązywać. 
litej Ludowej (dalej: PRL). Zgodnie z nową ustawą, każdy podlegający lustracji musiał wystąpić do Instytutu Pamięci Narodowej (dalej: IPN) o potwierdzenie istnienia materiałów o jego ewentualnej współpracy z organami PRL. Potwierdzenie należało przedstawić pracodawcom lub wyborcom ${ }^{8}$.

Nowelizacja autorstwa Prezydenta RP Lecha Kaczyńskiego zwiększyła liczbę funkcji publicznych podlegających lustracji do 53 i sprecyzowała pojęcie współpracy. Prezydent przywrócił oświadczenia lustracyjne zamiast zaświadczeń IPN. Miało je badać nowe biuro IPN, a ich prawdziwość - sądy okręgowe. Istotnym novum było przywrócenie procedury karnej wraz z obowiązującą w niej zasadą domniemania niewinności. Konsekwencją prawomocnego wyroku stwierdzającego „kłamstwo lustracyjne” miał być 10-letni zakaz pełnienia funkcji publicznych 9 .

Temat lustracji i nowej ustawy (oraz jej nowelizacji) przez dłuższy czas nie schodził z pierwszych stron gazet. $\mathrm{Z}$ niecierpliwością oczekiwano orzeczenia TK. We wniosku grupy posłów SLD znalazły się zarzuty wobec ponad 70 przepisów. Posłowie wnosili także o uznanie ustawy lustracyjnej za niezgodną z Konstytucją w całości. Osobny wniosek złożył również Rzecznik Praw Obywatelskich (dalej: RPO). TK postanowił rozpoznawać je wspólnie. Przekazał pisma Marszałkowi Sejmu i Prokuratorowi Generalnemu, którzy odrzucili zarzuty, równocześnie domagając się odroczenia rozprawy. Trybunał nie przystał na tę prośbę i wyznaczył termin na 9-11 maja 2007 r. ${ }^{10}$ Pierwszego dnia rozprawy Arkadiusz Mularczyk, poseł PiS reprezentujący Sejm przed TK, jeszcze raz wystąpił o odroczenie rozprawy. Kiedy sędziowie się na to nie zgodzili, zgłosił kolejny wniosek, żądając wyłączenia ze sprawy 4 sędziów zarzucając im stronniczość. TK odrzucił wszystkie inicjatywy A. Mularczyka, ale mimo to 10 maja - drugiego dnia rozprawy poseł ponownie wystąpił o odroczenie. Tym razem powołał się na materiały IPN, z których miało wynikać, że dwaj sędziowie TK - Marian Grzybowski i Adam Jamróz - byli kontaktami operacyjnymi SB. Obaj zaprzeczyli. Jednak Jerzy Stępień, prezes TK, podjął decyzję, by wykluczyć ich ze składu orzekającego. Mimo tych wydarzeń, 11 maja TK

${ }^{8}$ J. Woleński, Lustracja..., op. cit., s. 99-116.

${ }^{9}$ Ibidem, s. 115-120.

${ }^{10}$ Zdaniem J. Woleńskiego, wniosek o odroczenie był celowym zabiegiem, by przesunąć termin na drugą połowę maja. Wtedy to oświadczenia lustracyjne powinny znaleźć się już w IPN, a osobom, które ich nie złożyły, groziłaby utrata funkcji. Ibidem, s. 121-122. 
wydał wyrok. Trybunał ocenił 39 przepisów ustawy lustracyjnej jako niezgodnych z Konstytucją. Wśród nich znalazły się m.in.: preambuła oraz przepis zawierający definicję współpracy, a także przepisy regulujące lustrację dziennikarzy i naukowców, zaliczenie współpracy z organami państw obcych do współdziałania ze służbami PRL czy sposób udostępniania danych z IPN. TK wskazał na niewłaściwość tak surowych sankcji za złożenie oświadczenia fałszywego lub niezłożenie go w terminie, niewłaściwość tytułu wzoru oświadczenia, jak również niedopuszczalność anulowania wyniku wyborów przez pozbawienie mandatu. TK zarzucił ustawie, że narusza standardy legislacji (chodziło m.in. o nieodpowiednie vacatio legis czy ograniczenia zasady domniemania niewinności) i pogarsza ochronę prawną ${ }^{11}$. Po wyroku jedni politycy nie szczędzili krytyki sędziom TK, inni pochwał. Odrębne poglądy pojawiły się również w prasie.

\section{PODZIAE BADANYCH PUBLIKACJI PRASOWYCH}

W CELU ZBADANIA, jak temat lustracji przedstawiany jest na łamach dwóch, należących do najbardziej poczytnych w Polsce i uznawanych za opozycyjne względem siebie, dzienników - GW i Rz - wybrano okres tygodnia przed i tygodnia po wydaniu przez TK wyroku z 11 maja 2007 r. dotyczącego ustawy lustracyjnej ${ }^{12}$. Wtedy to na łamach obu gazet trwała dyskusja zarówno nad ustawą, jak i samą lustracją. Była to jednocześnie ostatnia, jak do tej pory, szeroka polska debata medialna odnośnie problematyki lustracyjnej. Równocześnie wypada przytoczyć pogląd Pawła Śpiewaka, że ukształtowane głównie w 1992 r. argumenty zwolenników i przeciwników lustracji nie uległy od tego czasu zasadniczej zmianie ${ }^{13}$.

${ }^{11}$ Wyrok Trybunały Konstytucyjnego z dnia 11 maja 2007 r. (OTK 2007, sygn. $\mathrm{K}$ 2/07).

${ }^{12}$ Według opracowania portalu Wirtualnemedia.pl z dn. 7 maja 2010 r. w I kwartale 2010 r. GW zajęła wśród dzienników ogólnopolskich drugie miejsce pod względem sprzedaży (ponad 310 tys. sprzedanego nakładu dziennie). Rz uplasowała się na miejscu czwartym (ponad 116 tys. sprzedanego nakładu). Wzrosła sprzedaż jedynie „Dziennika Gazety Prawnej”, http://www.wirtualnemedia.pl/artykul/wzrosla-sprzedaz-jedyniedziennika-gazety-prawnej, 17.05.2010 r.

${ }^{13}$ P. Śpiewak pisał: „Amunicja” ideowa od wiosny 1992 r. zwolenników i przeciwników lustracji nie uległa poważniejszym zmianom. Często można wręcz odnieść wrażenie déjà vu: to już było powiadam, gdy słyszę po raz kolejny zdanie o haniebnej postawie, która polega na tym, że wierzymy bardziej ubeckim archiwom niż słowu naszego kolegi i jego znajomych, albo też, gdy druga strona powiada, że antylustratorzy boją się o siebie i o swoich znajomych, dlatego przed wszelkimi przeglądami dawnych akt uciekają. Pojawiły się w ciągu tych 20 lat nowe prawa, powstały instytucje pamięci, zmieniały 
Analizie poddano 114 publikacji prasowych ${ }^{14}$. Od 4 do 18 maja 2007 r. w GW ukazało się 58 artykułów dotyczących lustracji. Z kolei $\mathrm{Rz}$ opublikowała w tym czasie 56 tekstów poruszających ten temat. Na potrzeby badania publikacje podzielono na dziennikarskie (pisane przez dziennikarzy i publicystów) oraz niedziennikarskie (pisane przez osoby niepracujące w zawodzie dziennikarza). Wśród artykułów dziennikarskich wyróżniono teksty informacyjne oraz perswazyjne (opinie, komentarze, felietony, teksty publicystyczne). Z kolei publikacje niedziennikarskie podzielono na wywiady i artykuły osób niezwiązanych z prasą (można je umownie nazwać artykułami ekspertów) ${ }^{15}$. Obie gazety przez dwa tygodnie opublikowały niemal identyczną liczbę artykułów poszczególnych kategorii. W GW ukazało się 26 artykułów informacyjnych, 19 perswazyjnych, 7 wywiadów oraz 6 opinii ekspertów. Rz opublikowała 25 artykułów informacyjnych, 19 perswazyjnych, 8 wywiadów i 4 teksty ekspertów. Dzienniki różniły się nieznacznie liczbą publikacji zamieszczanych danego dnia. Najwięcej tekstów nt. lustracji ukazało w poniedziałek 14 maja $^{16}$. GW opubliko-

nieco drużyny lustratorów i antylustratorów, wychodziły kolejne afery, ale argumenty, zresztą nie tylko w Polsce, od lat są w miarę podobne”. P. Śpiewak, Problem lustracji $w$ dyskursie prasowym po 1989 r., [w:] Retoryka i polityka, red. M. Czyżewski, Warszawa 2010, s. 222.

${ }^{14}$ Artykuły będące tematami z pierwszej strony, a co za tym idzie: ukazujące się na pierwszej i jednej z kolejnych stron, liczono jako jedną publikację. Podobną zasadę przyjęto przy komentarzach, które ukazywały się bezpośrednio pod głównym tekstem jako jego uzupełnienie. W bibliografii analizowanych artykułów prasowych wyróżniono wszystkie tytuły publikacji (osobno te będące zajawkami na pierwszej stronie, osobno te będące kontynuacją zajawek, czyli teksty główne), stąd ich większa liczba niż 114. Zob. Załącznik. Bibliografia artykułów prasowych.

${ }^{15}$ Zastosowany podział ma dwa podstawowe cele. Po pierwsze, pozwala rozróżnić poglądy prezentowane przez dziennikarzy gazety, od stanowisk przedstawianych przez osoby tematem zainteresowane, ale niezobowiązane linią programową dziennika. Po drugie, podział w ramach publikacji dziennikarskich pozwala na zbadanie sposobu przedstawiania problemu lustracji w artykułach, które mają na celu przekazanie czytelnikom nowych informacji oraz w tekstach, które są przedstawieniem poglądów autora. Rozróżnienie wydaje się istotne, ponieważ w tych pierwszych dziennikarz teoretycznie powinien zachować obiektywizm, ale już sam dobór informacji, ich kolejność oraz cytowane wypowiedzi nakreślają pewien sposób widzenia autora. Wyróżnienie tekstów niedziennikarskich ma na celu zbadanie, czyje poglądy gazety najczęściej przedstawiają oraz czy dobór tych osób wykazuje się pewną tendencją. Natomiast dodatkowy podział na wywiady i artykuły ekspertów wydaje się konieczny, ponieważ są to dwie różne formy wypowiedzi. Poza tym, wywiad jest prowadzony przez dziennikarza, to on narzuca temat i kierunek rozmowy. Z kolei tekst autorstwa osoby niezwiązanej z prasą jest od początku do końca jej inwencją. Niemniej to redakcja decyduje, czyj tekst opublikować.

${ }^{16}$ Jest to zrozumiałe, biorąc pod uwagę, że w piątek 11 maja wyrok zapadł wieczorem. Gazety nie miały wiele czasu na przygotowanie publikacji na sobotę, stąd większa 
wała ich 12, a Rz 10 .

\section{PoGląDY DZIENNIKARZY GW i RZ NA TEMAT LUSTRACJI}

BADANIE WYKAZAŁO, że w większości artykułów autorzy obu gazet nie wyrażali wprost swoich poglądów na temat lustracji. Nie oznacza to, że nie było wcale takich przypadków. Warto podkreślić, że przeważająca liczba tekstów, w których ujawniano wprost swoje poglądy, to artykuły perswazyjne. Wyrażali je czołowi publicyści obu gazet. Spośród 58 tekstów, które ukazały się na łamach GW, poglądy autorów pojawiły się w 12 artykułach - 9 razy były to teksty perswazyjne, 2 razy artykuły napisane przez ekspertów i 1 tekst informacyjny. Wszystkie przedstawione poglądy były nastawione przeciwko lustracji. Autorzy publikacji w Rz ujawnili swoje zdanie 16 razy (na 56 publikacji). Poglądy prolustracyjne zawierało 13 tekstów perswazyjnych, 1 artykuł eksperta i 1 informacyjny. Daje to łączną liczbę 15 publikacji opowiadających się za lustracją. Podkreślenia wymaga tu wydrukowanie przez Rz 1 tekstu perswazyjnego, którego autor - Jacek Żakowski - był przeciwny lustracji ${ }^{17}$. Chcąc pokazać, jak autorzy prezentowali swoje poglądy, wybrano przykładowe fragmenty tekstów z obu gazet ${ }^{18}$.

ich liczba w poniedziałek. Poza tym, badania czytelnictwa od lat wykazują, że poniedziałkowe wydania gazet są chętniej kupowane niż bywa to w inne dni.

${ }^{17}$ Trzeba także dodać, że J. Żakowski nie jest publicystą Rz. Jest jednym z założycieli GW, przez wiele lat dla niej pracowal, aktualnie wciąż pisze na jej lamach komentarze. Obecnie J. Żakowski jest dziennikarzem tygodnika „Polityka”, prowadzi także audycję w radiu TOK FM. Łączy się go zatem (i słusznie) z mediami konkurencyjnymi w stosunku do Rz, prezentującymi zupełnie inną linię programową. Jednak prasa bardzo często dla równowagi zamieszcza teksty, najczęściej komentarze, autorstwa osób deklarujących odmienne od redakcji poglądy. Ten zabieg ma na celu stworzenie wrażenia obiektywizmu. Zob. J. Żakowski, Nasze cierpienia $w$ lustracyjnym piekle, Rzeczpospolita z dnia 18 maja 2007, s. A9.

${ }^{18}$ I tak Bronisław Wildstein pisał na łamach Rz: „Najlepszym i najprostszym rozwiązaniem byłoby upublicznienie akt, oczywiście z wyłączeniem informacji dotyczących spraw intymnych poszkodowanych. Pełna jawność uniemożliwiłaby „grę teczkami”, szantaże, przecieki i temu podobne działania, którymi tak oburzają się przeciwnicy lustracji. (...) Upublicznienie archiwów IPN oddałoby społeczeństwu jego własność, gdyż materiały te stanowią najpełniejszy zasób wiedzy o komunistycznej Polsce. (...) Będzie to jednak wstrząs ozdrowieńczy. Doprowadzi pewnie do przewartościowania wielu postaci i środowisk, ale oznaczać będzie to jedynie, że obecnie istniejące hierarchie ufundowane zostały na fałszu”. B. Wildstein dopasował argumenty wysuwane przez osoby przeciwne lustracji do własnego zdania. Tak, by wskazać, że zarzuty wobec lustracji właśnie lustracją można zwalczyć. Autor odwołał się do społeczeństwa, wskazał, że jawność archiwów IPN jest prawem każdego (w domyśle: czytelnika). Prościej i bardziej dobitnie o lustracji pisał Adam Michnik, redaktor naczelny GW: „Zawsze byłem zdania, że spektakl publicznego grzebania w ubeckich raportach i donosach - zwany ele- 
Można wnioskować, że dziennikarze obu tytułów w większości artykułów nie ujawniali swoich poglądów wprost, ponieważ starali się zachować neutralność, a przynajmniej stworzyć takie pozory. Wydaje się to zrozumiałe, biorąc pod uwagę fakt, iż zazwyczaj medium stara się uchodzić za bezstronne i obiektywne, a raczej: maskować swoją tendencyjnośćc ${ }^{19}$. Musi zatem unikać opowiadania się wprost autorów po jednej stronie konfliktu i ujawniania ich sympatii politycznych. O ile jednak owa bezstronność i obiektywność jest pożądana w gatunkach informacyjnych, o tyle nie jest już cechą gatunków perswazyjnych (publicystycznych ${ }^{20}$ i jak wykazała analiza, potwierdza się to w GW i Rz. Podobieństwo między publikacjami zamieszczonymi w obu dziennikach polega więc na tym, że w artykułach informacyjnych unikano jednoznacznych deklaracji politycznych, ale teksty perswazyjne nie były

gancko lustracją - jest procederem nierozumnym i niemoralnym. Ceną zdemaskowania pewnej liczby agentów - choćby nie było wśród nich nikogo, kto zajmowałby najważniejsze stanowiska w państwie - jest krzywda wielu uczciwych ludzi. Lustracja prowadzi do upowszechnienia klimatu podejrzliwości i strachu”. Autor odwoływał się przede wszystkim do emocji. Pisał o ludzkiej krzywdzie i niesprawiedliwości, by wzbudzić w odbiorcach niepokój. Nie szczędził negatywnych określeń, by jednoznacznie wyrazić swoje zdanie. Zob. B. Wildstein, Ozdrowieńczy wstrząs jawności, Rzeczpospolita z dnia 12 maja 2007, s. A2. A. Michnik, Adam Michnik: otwórzmy teczki, Gazeta Wyborcza z dnia 14 maja 2007, s. 1.

${ }^{19}$ Wśród medioznawców i innych naukowców od lat trwają spory o dziennikarski obiektywizm. Jedni uważają, że istnieją media obiektywne, a już na pewno mogą takie istnieć, drudzy, że dziennikarski opis nie może i nie powinien być obiektywny. Wielu badaczy uważa, że każda gazeta czy telewizja ma swoją jasno określoną linię programową. Niektórzy naukowcy są zdania, że dominacja jednego dyskursu nie musi wykluczać obiektywizmu. Może się bowiem zdarzyć, że charakter opisywanego zjawiska, wydarzenia, postawy pasuje do dominującego w danym medium sposobu relacjonowania. Zob. M. Mrozowski, Media masowe. Władza, rozrywka i biznes, Warszawa 2001, s. 304-309.

${ }^{20}$ Informacja ma na celu przedstawianie faktów i zdarzeń, natomiast publicystyka ma przekazywać sądy i opinie. Według Michała Szulczewskiego informacja rozszerza możliwość uczestniczenia odbiorcy w wydarzeniach, natomiast publicystyka pogłębia ich przeżywanie. M. Szulczewski stwierdzil, że ,jeżeli informacja dziennikarska jest nadążaniem za nowymi faktami, to publicystyka - najogólniej biorąc - jest reagowaniem na te fakty. Mamy tu oczywiście do czynienia z reakcją intelektualną i emocjonalną, a ściślej jeszcze - z zamiarem wywołania takiej reakcji u odbiorcy”. To stwierdzenie potwierdza więc, że o ile bezstronność jest (a raczej powinna być) cechą informacji, o tyle nie przypisuje się jej publicystyce (tu: nazwanej szerzej artykułami perswazyjnymi). Dopełnieniem tych słów jest także definicja publicystyki wg M. Szulczewskiego: „publicystyka to aktualne, publiczne, tendencyjne oświetlanie wszelkich zagadnień społecznych”. Podkreślenia wymaga tu określenie „tendencyjne” - a więc zgodnie z przyjętym wzorcem, poglądem czy przekonaniem. Zob. M. Szulczewski, Informacja. Publicystyka, [w]: Teoria i praktyka dziennikarstwa, red. B. Golka, Warszawa 1964. 
już ich pozbawione. Publicyści wyrażali wprost swoje poglądy dotyczące lustracji. W tym przypadku na łamach obu gazet ujawniły się już dwie, zasadniczo różne tendencje, stawiając dzienniki w opozycji.

\section{ARGUMENTACJA PRO- I ANTYLUSTRACYJNA}

O ILE DZIENNIKARZE OBU GAZET starali się nie pisać wprost o swoich poglądach, o tyle znacznie częściej przytaczali w kontekście ustawy i wyroku TK argumenty, pozwalające w miarę łatwo zaklasyfikować się jako pro- lub antylustracyjne. W trakcie analizy treści artykułów prasowych brano pod uwagę zarówno argumenty wysuwane wprost przez autora, jak i te, które pojawiły się w cytowanych wypowiedziach. Często takich pro- lub antylustracyjnych uzasadnień można było się doszukać także w komentarzach, tytułach, a nawet pytaniach zadawanych w trakcie wywiadu. Podkreślić należy, że w obu gazetach pojawiały się zarówno argumenty za, jak i przeciw lustracji, jednak pierwsze albo drugie, w zależności od tytułu, głównie po to, by poddać je krytyce, zanegować. Po przeprowadzeniu analizy trudno nie zgodzić się z przytoczoną już tezą P. Śpiewaka, że argumenty przeciwników i zwolenników lustracji od lat pozostają takie same. Socjolog wyróżnił 6 zasadniczych tez (a raczej grup argumentów) stawianych przez antylustratorów oraz 3 grupy argumentów za lustracją ${ }^{21}$. I faktycznie, wszystkie one pojawiają w artykułach GW i Rz z maja 2007 r. Zgodnie z ujawnioną tendencją, autorzy opublikowanych w GW treści wysuwali przede wszystkim argumenty przeciwko lustracji, natomiast dziennikarze i eksperci $\mathrm{Rz}$ opowiadali się za. Wśród antylustracyjnych tez w GW najczęściej pojawiało się odwołanie do praw oraz wolności człowieka, które w procesie lustracji są łamane i ograniczane ${ }^{22}$. Innymi argumentami, które

${ }^{21}$ P. Śpiewak argumenty przeciwko lustracji dzieli na: techniczne (niekompletność, zafałszowanie akt SB), moralne (chodzi tu o okrucieństwo i agresję zwolenników lustracji), dotyczące porządku prawnego (odwoływanie się do demokratycznego państwa prawa, Konstytucji, praw człowieka), społeczno-kulturowe (lustracja rodzi nienawiść, kłótnie, strach, jest grą i odwetem politycznym), atakujące IPN jako zinstrumentalizowaną instytucję pełniącą rolę narzędzia politycznego, negujące znaczenie tajnych współpracowników w rządach. Argumenty prolustracyjne określa ogólnie w 3 tezach, jednak każda z nich mieści w sobie jeszcze wiele innych, ale podobnych argumentacyjnie, założeń. Te główne tezy za lustracją to: prawo do informacji i wiedzy o przeszłości, racja stanu i suwerenność oraz poczucie sprawiedliwości i moralność. Zob. P. Śpiewak, Problem..., op. cit., s. 224-236.

${ }^{22}$ Tym argumentem posłużył się m.in. Mirosław Czech, pisząc: „Warto o tym mówić, ponieważ to nie PO zaskarżyła ustawę lustracyjną do TK i nie ona stanęła w obronie setek tysięcy obywateli zmuszanych do naruszenia prawa i własnej godności. (...) Dlatego walka z TK była tak zaciekła i bezpardonowa. Obywatel miał zobaczyć, że nikt nie jest 
przywoływano w GW najczęściej, były: przekonanie, iż lustracja służy politykom do gry, szantażu i zdobycia władzy, jest niezgodna z Konstytucją, prowadzi do podejrzeń i pomówień, jest narzędziem zemsty ${ }^{23}$. Na łamach GW przytaczano także argumenty zwolenników lustracji. Jak już wspomniano, celem była przede wszystkim ich krytyka. Należy zauważyć, że autorzy GW często, posługując się tezami prolustracyjnymi (najczęściej za pomocą cytowanych wypowiedzi), pozostawiali je bez komentarza. Wtedy jednak zestawiali je z innymi wypowiedziami lub opisami sytuacji, które w swej istocie negowały argumenty za lustracją. Ważną cechą publikacji GW jest także częste posługiwanie się ironią zamiast bezpośredniej krytyki. Wypowiedzi prolustracyjne przytaczane przez dziennikarzy tego dziennika najczęściej odnosiły się do takich wartości, jak konieczność rozliczenia z przeszłością, przejrzystość życia publicznego oraz prawo obywateli do informacji. W toku analizy okazało się jednak, że nie były to główne argumenty zwolenników lustracji. Autorzy Rz, przedstawiając ich poglądy, pisali o sprawiedliwości, prawdzie, racji stanu, wiedzy o przeszłości oraz bezpieczeństwie państwa ${ }^{24}$. Argumenty przeciwko lustracji pojawiające się w publikacjach Rz również nie pokrywały się z tymi, które najczęściej pojawiały się w GW. W argumentacji antylustracyjnej przytaczanej na łamach Rz najczęściej podkreślano bowiem, że lustracja oznacza sugerowanie się kłamstwami tajnych służb PRL, stosowanie odpowiedzialności zbiorowej, polityczne działanie IPN. Tego typu tezy uzewnętrzniano głównie w cytowanych wypowiedziach albo tekstach perswazyjnych, traktując je jako przyczynek do polemiki ${ }^{25}$. Podczas

bezpieczny, bo na każdego IPN pod osłoną nocy znajdzie jakiegoś haka”. M. Czech, Trybunat obronit demokracje, Gazeta Wyborcza z dnia 12 maja 2007, s. 10.

${ }^{23}$ Takie argumenty przedstawił chociażby Marcin Bosacki, pisząc: „Kaczyński jest w coraz większym kłopocie. Nie, nie dlatego, że TK oskalpował jego model lustracji. Kłopot polega na tym, że choć lustracja trwa już długo, choć półtora roku służby specjalne są na każde jego skinienie, choć powołał CBA i nowy wywiad wojskowy - efektu nie widać. Efektem miało być ujawnienie Układu, dotarcie do Jądra oplatającej kraj Pajęczej Sieci. A tu nic: trochę złapanych łapowników, trochę ujawnionych agentów, kilku nawet prawdziwych. Nawet powszechne ujawnienie teczek, jeśli do tego dojdzie, nie udowodni tezy o spisku, który niszczy Polskę”. M. Bosacki, Premier i stu agentów, Gazeta Wyborcza z dnia 15 maja 2007, s. 2.

${ }^{24}$ Wylicza je wprost w swoim artykule Agnieszka Romaszewska: „Bez wątpienia jawność życia publicznego jest wielką wartością, wielką wartością jest ochrona państwa przed działaniem historycznie osadzonych układów, a jego funkcjonariuszy przed szantażem, jeszcze większą wartością jest dziejowa sprawiedliwość”. A. Romaszewska, Ratujmy z lustracji, co się da, Rzeczpospolita z dnia 16 maja 2007, s. A10.

${ }^{25}$ Dobrym przykładem jest Bronisław Wildstein, który polemizował ze tymi, którzy publicznie opowiadali się przeciwko lustracji. Przytaczał część ich argumentów, a więc 
analizy treści artykułów obu gazet zauważono, że dziennikarze Rz częściej niż ci z GW krytykowali wprost przeciwników lustracji, rzadziej posługując się natomiast ironią.

To właśnie przyjęty typ relacji, a więc sposób przedstawiania zagadnień związanych z lustracją, ustawą autorstwa PiS, wydarzeniami, które miały miejsce przed i w trakcie rozprawy TK oraz samego wyroku, najwyraźniej obrazowały, co na temat lustracji i orzeczenia TK sądzą dziennikarze, publicyści i eksperci obu dzienników. W obu gazetach argumenty świadczące o określonym stosunku do problemu lustracji pojawiały się jako bezpośrednie komentarze autorów, ale przede wszystkim przedstawiano je za pomocą wypowiedzi znanych osób, odpowiedniego doboru i kolejności informacji oraz drobnych manipulacji językowych (np. w tytułach) ${ }^{26}$. Analiza treści artykułów potwierdziła tendencje ujawnione przez publicystów w tekstach perswazyjnych: autorzy publikacji na łamach GW przytaczali argumenty przeciwko, a piszący w Rz za lustracją. Treści te zdecydowanie się więc od siebie różniły. Jednak, co już wykazano, wystąpiło także podobieństwo: w artykułach obu gazet pojawiały się również argumenty drugiej strony. To znów należy uznać za próbę obiektywizacji przekazu i zachowania równowagi ${ }^{27}$. O tym, że ta relacja dialektyczna (powtarzając za Edwardem Epstainem) była w pełni kontrolowana, może świadczyć fakt, iż argumenty przytaczane jako stanowisko drugiej strony nie pokrywały się z tymi, które druga strona najczęściej podawała. Skoro bowiem argumenty, np. przeciwko lustracji przytaczane przez autorów publikacji w Rz (jak już ustalono, zwolenników lustracji), nie pokrywały się z tymi, które pojawiały się w artykułach GW (przeciwnych lustracji), można stwierdzić, że dziennikarze $\mathrm{Rz}$ dobierali tylko takie poglądy,

tylko te wybrane, by poddać je całkowitej krytyce. I pisał: „Powtarzane w nieskończoność nonsensy o „upokorzeniu”, jakim ma być wypełnienie deklaracji lustracyjnej, albo „odpowiedzialności zbiorowej”, która polega na obowiązku lustracyjnym, dla wielu stały się bezrefleksyjnymi oczywistościami. Do antylustracyjnego frontu należą również postkomuniści, dla których niebezpieczne jest odsłonięcie prawdy, czyli efekt lustracji”. B. Wildstein, Zwycięstwo antylustracyjnego frontu, Rzeczpospolita z dnia 14 maja 2007, s.A10 .

${ }^{26}$ Dla przykładu: P. Semka w tekście pt. Polityka puka do bram Trybunatu przypomina, że kilkoro sędziów TK ma za sobą karierę polityka. Tytuł jest więc sugestią, że obradujący nad lustracją TK nie jest apolityczny i bezstronny. Zob. P. Semka, Polityka puka do bram Trybunatu, Rzeczpospolita z dnia 11 maja 2007, s. A11.

${ }^{27}$ Edward J. Epstain, badacz amerykańskich sieci telewizyjnych, nazywa ten typ relacji dialektycznym. Zgodnie z nim zagadnienia kontrowersyjne ukazuje się z dwóch przeciwstawnych punktów widzenia. Zob. M. Mrozowski, Media..., op. cit., s. 313-314. 
które były dla nich wygodne (np. łatwe do podważenia) ${ }^{28}$. Miało to na celu stworzenie pozorów obiektywności, ale tak naprawdę prowadziło do zachowania zgodności z linią programową gazety.

\section{STANOWISKO WOBEC USTAWY Z DNIA 18 PAŹDZIERNIKA 2006 R.}

PRAKTYCZNIE WSZYSTKIE PUbLIKACJE zamieszczane $\mathrm{w}$ obu gazetach $\mathrm{w}$ tygodniu poprzedzającym wyrok TK zawierały w treści odniesienia do zaskarżonej ustawy. Czasem jej zapisy komentowali sami autorzy artykułów, ale częściej zamieszczano wypowiedzi polityków lub konstytucjonalistów. Stanowisko autorów GW wobec ustawy było jasne - wszystkie analizowane publikacje przedstawiały ją w sposób negatywny jako niezgodną z konstytucją, naruszającą wolność i godność człowieka. Znacznie ciekawszą była reakcja Rz, która, mimo prolustracyjnego nastawienia, drukowała zarówno teksty broniące, jak i krytykujące ustawę ${ }^{29}$. Autorzy stawiali jednak tezę, że nawet złego prawa trzeba przestrzegać ${ }^{30}$. Uznając, że jest to zdanie stające $\mathrm{w}$ obronie ustawy lustracyjnej, podczas analizy stwierdzono, że liczba artykułów broniących ustawy nieznacznie przeważyła nad tekstami krytycznymi. Na uwagę zasługuje również fakt, że o ile przed orzeczeniem przez TK wyroku w Rz pojawiały się artykuły broniące przepisów, o tyle po zakończeniu rozprawy autorzy skupili się na krytyce i podważaniu bezstronności sędziów TK. Autorzy publikacji w GW pozostali natomiast przy szerokiej krytyce ustawy ${ }^{31}$.

${ }^{28}$ Oczywiście, analogicznie, sytuacja powtarza się także w drugą stronę: autorzy publikacji w GW dobierali takie argumenty za lustracją, które im odpowiadały.

${ }^{29}$ Piotr Andrzejewski, senator PiS, pisał: „Aktualny stan lustracji to przykład nieadekwatnej do potrzeby ujawnienia prawdy o nas samych nieporadnej legislacji, która obraca się przeciwko osiągnięciu celów, którym miała służyć”. Jednak tego samego dnia, obok krytyki ustawy znalazł się także tekst jej broniący: „W wypadku ustawy lustracyjnej nie doszło do naruszenia demokracji ani reguł stanowienia prawa. Czy prawo winno zatem być akceptowane w zależności od indywidualnego uznania?” P. Andrzejewski, Lustracja $w$ imię konstytucji to powszechny dostęp do teczek, Rzeczpospolita z dnia 7 maja 2007, s. C7, B. Wildstein, Demokracja wedtug europejskiego salonu, Rzeczpospolita z dnia 7 maja 2007, s. A10.

${ }^{30}$ Jan Woleński krytykował taką argumentację, wskazując, że osoby wrogo nastawione do starego systemu właśnie go naśladują. J. Woleński uważa, że taki sposób myślenia jest charakterystyczny dla społeczeństwa komunistycznego: „Gdy słyszę, że ustawa lustracyjna jest wprawdzie nienajlepsza i może nawet zbyt surowa, ale trzeba się jej podporządkować, bo to prawo, a prawa mają słuchać wszyscy, to zaraz sobie przypominam nakłanianie do przestrzegania rygorów stanu wojennego. I chociaż reżim lustracyjny i wymagania stanu wojennego należą do zupełnie innych światów, podobieństwo w argumentacji jest znaczne w obu przypadkach”. J. Woleński, Lustracja..., op. cit., s. 11.

${ }^{31}$ Ich postawa wydaje się zrozumiała, ponieważ wyrok TK dostarczył im dodatko- 
Taka postawa odczytana na łamach GW wydaje się zrozumiała wobec przedstawionego już krytycznego podejścia autorów do lustracji w ogóle. Żaden z dziennikarzy GW nie stanął w obronie ustawy. Nie przeprowadzono także ani jednej rozmowy z osobą, która by ustawę poparła. W analizowanych publikacjach ograniczono się jedynie do cytowania polityków, o których wiadomo było, że stoją po stronie lustracji. Jednak w ciągu badanych dwóch tygodni tylko raz zacytowano ich słowa, które wprost broniły krytykowanego aktu normatywnego ${ }^{32}$. Dziennikarze GW nie zachowali zatem w swoich relacjach obiektywności. Trudno jednoznacznie stwierdzić, dlaczego nie przywołali ani jednego poglądu broniącego ustawy. Można tylko domniemywać, że redakcja uznała przepisy ustawy lustracyjnej za jednoznacznie sprzeczne z Konstytucją, więc nie chciała w żaden sposób dawać czytelnikowi do zrozumienia, że może być inaczej. Poza tym, przez cały marzec $2007 \mathrm{r}$. w GW ukazywały się różne artykuły, listy, wystąpienia przedstawicieli środowiska naukowego, w których wyrażali oni sprzeciw wobec rozliczeń z przeszłością. Była to cała seria tekstów (nazwana przez redakcję „Lustracją wykształciuchów”) przeciwko ustawie autorstwa PiS. Można więc sądzić, że redakcja wyszła z założenia (chyba słusznie), iż hipokryzją byłoby publikowanie później materiałów broniących ustawy. Nie zmienia to jednak faktu, że w ten sposób piszący na łamach GW autorzy nie zachowali bezstronności i obiektywizmu. Zachowali jednak przyjętą wcześniej linię programową. O tym, że można stworzyć pozory bezstronności świadczą z kolei przedstawiające zdanie obu stron (za i przeciw ustawie) publikacje Rz. Biorąc jednak pod uwagę ujawnione podczas analizy tendencje i liczbę prolustracyjnych artykułów opublikowanych w Rz, należałoby się zastanowić, czy wypowiedzi i postawy krytykujące ustawę były zamieszczane w celu zachowania bezstronności, czy może dlatego, że ten akt prawny faktycznie zawierał wiele niedopracowanych i niekonstytucyjnych zapisów (co potwierdził wyrok TK). Na taki stan rzeczy może wskazywać również inny fakt. Pomimo że Rz zamieściła zdania przeciwne, na jej łamach i tak ukazało się więcej tekstów przychylnych ustawie. Jednak po wyroku TK stwierdzającym niekonstytucyjność wielu jej przepisów, autorzy Rz, poza nielicznymi przypadkami, odeszli od argumentacji sprzyjającej

wych argumentów, a także fachowego i prawnego potwierdzenia, że prowadzona przez nich krytyka ustawy lustracyjnej była słuszna.

${ }^{32}$ Były to wypowiedzi Prezydenta Lecha Kaczyńskiego podczas uroczystości z okazji Święta Konstytucji 3 Maja. Zob. P. Wroński, Konstytucja 3 maja z lustracją w tle, Gazeta Wyborcza z dnia 4 maja 2007, s. 4. 
ustawie. Można więc wnioskować, że już wcześniej zdawali sobie sprawę z wad ustanowionych przepisów, ale chcieli zachować swoje prolustracyjne stanowisko. Kiedy TK potwierdził obawy co do niekonstytucyjności ustawy, dziennikarze Rz zmienili argumentację, podważając niezawisłość i bezstronność sędziów TK, co pozwoliło im zostać przy stanowisku popierającym lustrację.

\section{PogLĄDY I OPINIE PREZENTOWANE W OBU GAZETACH}

W OBU DZIENNIKACH, przekazując informacje, ale także w celu potwierdzenia stawianych tez, wielokrotnie cytowano wypowiedzi polityków, ekspertów, osób bezpośrednio zainteresowanych sprawą lustracji. Należy przy tym zauważyć, że dziennikarze Rz robili to częściej niż ci z GW. W obu gazetach najczęściej cytowano polityków PiS. Na łamach Rz ich wypowiedzi pojawiły się 52 razy, w GW 47 razy. Najwięcej znalazło się ich w tekstach relacjonujących rozprawę przed TK, a także w artykułach opublikowanych tuż po wyroku. Pod względem liczby cytowań, w następnej kolejności w Rz znalazły się wypowiedzi polityków Platformy Obywatelskiej (dalej: PO) i SLD (w obu przypadkach były to 24 wypowiedzi), czyli opozycji. Dla porównania w GW cytowano przedstawicieli PO tylko 8, a SLD 6 razy. Za to osobą, którą - poza politykami PiS - autorzy GW cytowali najczęściej, był Jerzy Stępień, ówczesny prezes TK. Pod tym względem w Rz jego wypowiedzi znalazły się dopiero na szóstym miejscu. Warto również wskazać, że na łamach $\mathrm{Rz}$ cytowano Janusza Kurtykę, prezesa IPN, 23 razy, podczas gdy w GW nie znalazła się ani jedna jego wypowiedź. Analogicznie, GW opublikowała 5 wypowiedzi Bronisława Geremka, a Rz nie zrobiła tego ani razu. Godny uwagi wydaje się również fakt, że dziennikarze Rz aż 19 razy cytowali notatki sporządzone przez esbeków, podczas gdy drugi dziennik zamieścił tylko 1 taki cytat. Istotne znaczenie mają także osoby, z którymi dziennikarze danej gazety przeprowadzili wywiady. GW w ciągu dwóch tygodni opublikowała 7 wywiadów. Rozmówcami byli: Norman Davies, Wisława Szymborska, Andrzej Arseniuk, Stanisław Salmonowicz, Bronisław Geremek i Jarosław Kaczyński. Ten ostatni wywiad to przedruk wybranych fragmentów z Rz - fragmentów bodaj najbardziej kontrowersyjnych. Rozmowa z A. Arseniukiem, rzecznikiem IPN, miała na celu wykazanie, kiedy i w jaki sposób poseł PiS A. Mularczyk zdobył akta dotyczące sędziów TK. Ani IPN, ani PiS nie wypadły w niej pozytywnie. Natomiast pozostali rozmówcy, to zdecydowani przeciwnicy PiS, a także jego modelu lustracji. W Rz ukazało się 8 wywiadów z: ks. Tadeuszem Isakowiczem-Zaleskim, Januszem 
Kurtyką, Hubertusem Knabe, Jarosławem Kaczyńskim, Adamem Strzemboszem, Andrzejem Zybertowiczem, Rafałem Gruzińskim oraz Wiesławem Johannem. Wszyscy wskazani rozmówcy to zwolennicy lustracji, którzy, w większości, po ogłoszeniu wyroku dotyczącego ustawy skrytykowali sędziów TK. Na łamach Rz ukazał się 1 wywiad z przeciwnikiem lustracji - Jerzym Szmajdzińskim z SLD ${ }^{33}$. Nie była to jednak osobna publikacja, ale krótka rozmowa dołączona do artykułu.

Rzeczą zrozumiałą wydaje się, że pod względem liczby cytowań autorzy obu gazet najczęściej przywoływali polityków związanych z PiS i otoczeniem Prezydenta Lecha Kaczyńskiego. Naturalne jest bowiem, że partia rządząca i urzędujący Prezydent pojawiają się w mediach najczęściej i to szczególnie ich działaniom przyglądają się dziennikarze. Temat lustracji pojawił się na łamach gazet także z powodu działalności rządu. To bowiem jego autorstwa była zaskarżona do TK ustawa lustracyjna. To również poseł PiS Arkadiusz Mularczyk reprezentował Sejm podczas rozprawy przed TK i to on wywołał kontrowersje podczas obrad. Należałoby więc skłaniać się do stwierdzenia, że właśnie z tych powodów na łamach obu gazet najczęściej cytowano polityków PiS. Różnica ujawniła się jednak przy komentarzach do tych wypowiedzi. O tym, że publikacje zamieszczane w obu dziennikach wyrażały jasno określone stanowisko zarówno w sprawie lustracji, jak i wyroku TK dotyczącego ustawy lustracyjnej świadczą trzy istotne fakty. Po pierwsze, analiza wykazała, że dziennikarze chętniej przywoływali wypowiedzi i postawy osób mających poglądy zgodne z linią programową redakcji niż takie, które były jej przeciwne. Po drugie, gazety publikowały wywiady z osobami podzielającymi prezentowane na łamach stanowisko. I wreszcie po trzecie, w obu wcześniejszych przypadkach zdarzało się tak, że w jednym z dzienników dana postać występowała kilkanaście razy, a w drugim w ogóle. Wszystko to więc świadczy, iż GW i Rz skrupulatnie przygotowywały materiał prasowy. Tak, by odzwierciedlał przyjętą przez redakcję linię programową. Dobór rozmówców i przedstawianych postaci ma w prasie duże znaczenie, ponieważ z jednej strony, dziennikarze mają zawsze wytłumaczenie, że prezentowali czyjeś a nie swoje własne poglądy, a z drugiej strony, ujawnianie spojrzenia większej liczby osób (najlepiej znanych i cenionych) podnosi wiarygodność i prestiż gazety. Trzeba również wspomnieć, że autorzy GW i Rz przedstawiali także poglądy niezgodne

${ }^{33}$ E. Olczyk, Lustracyjny szczyt u prezydenta, Rzeczpospolita z dnia 16 maja 2007, s. A3. 
z linią programową dziennika. Zapewne miało to na celu zachowanie pewnej równowagi. Poza tym, jeśli nie ma zdań przeciwnych, nie ma miejsca na polemikę i krytykę.

\section{GW I Rz WOBEC WYROKU TK}

CiekaWa sytuacja miała miejsce po ogłoszeniu przez TK wyroku. Wtedy ujawniły się największe różnice pomiędzy gazetami. O ile dziennikarze i eksperci na łamach GW wypowiedzieli się jednoznacznie pozytywnie na temat wyroku TK, o tyle zdawać się mogło, że dziennikarze Rz mieli trudność z określeniem własnego stanowiska. Podczas gdy następnego dnia po orzeczeniu TK autorzy GW pisali, że „zwyciężyła demokracja i poszanowanie prawa, a sędziowie nie ulegli zamachowi rządzących" 34 , w publikacjach $\mathrm{Rz}$ analizowano sytuację partii politycznych po wyroku (kto stracił, kto zyskał), pisano o nowym pomyśle na całkowite otwarcie archiwów IPN, publikowano obszerny reportaż na temat J. Kurtyki i równie obszerny wywiad z J. Kaczyńskim. Jedynym autorem, który wprost przedstawił swoje krytyczne zdanie na temat wyroku był B. Wildstein ${ }^{35}$. Jeśli chodzi o treść wyroku, to w Rz praktycznie w ogóle się do niego nie odniesiono. Jedynym zapisem, który wzbudził oburzenie i był podejmowany na łamach dziennika, było zamknięcie archiwów IPN dla dziennikarzy i historyków (do czasu poprawienia sprzecznego z Konstytucją przepisu). Zatem przy pytaniu o stanowisko autorów gazety wobec wyroku TK, stwierdzono, że można nie tyle określić stanowisko redakcji Rz wobec wyroku, ile wobec sędziów TK, których w tekstach gazety stanowczo krytykowano. Z kolei dziennikarze GW zdecydowanie wyrok chwalili. O stosunku redakcji obu gazet do wyroku TK świadczy także fakt, iż GW już następnego dnia opublikowała skróconą (co nie znaczy: krótką) wersję uzasadnienia, a w poniedziałek 14 maja przedrukowała wyrok w całości. Rz ograniczyła się tylko do wyliczenia niektórych uchylonych przepisów.

Argumenty, którymi posługiwali się dziennikarze GW przy ocenie wyroku TK, częściowo pokrywały się z argumentami przywoływanymi

${ }^{34}$ M. Czech, Trybunat obronit demokrację, Gazeta Wyborcza z dnia 12 maja 2007, S. 10.

${ }^{35}$ B. Wildstein napisał: „Znaczne ograniczenie ustawy lustracyjnej nie jest niespodzianką. Debata w TK, a zwłaszcza stosunek większości jego członków do lustracji nie pozostawiał w tej mierze żadnych wątpliwości”. Autor przyznawał, że prezydenckie poprawki wprowadziły do ustawy komplikacje i nadały jej ułomny kształt. Jednak, jego zdaniem, TK zakwestionował wiele ważnych i potrzebnych przepisów. A wszystko dlatego, że jego sędziowie byli stronniczy. B. Wildstein, Ozdrowieńczy wstrząs jawności, Rzeczpospolita z dnia 12 maja 2007, s. A2. 
przeciwko lustracji. O ile wcześniej na łamach GW pisano, że lustracja narusza prawa i wolności człowieka, o tyle po orzeczeniu dziennik publikował treści wskazujące, że TK ochronił państwo prawa, stanął na straży demokracji i Konstytucji ${ }^{36}$. Przyjęcie takiej argumentacji miało silny wydźwięk perswazyjny, ponieważ próbowało uświadomić odbiorcy, że uchylenie części przepisów ustawy obroniło podstawy, na jakich funkcjonuje państwo, a tym samym zapewniło każdemu obywatelowi bezpieczeństwo oraz poszanowanie jego praw i wolności. Najważniejszym argumentem podawanym przez dziennikarzy Rz przeciwko wyrokowi było twierdzenie, że TK usunął z ustawy wiele ważnych przepisów, a przez to wprowadził w państwie chaos. Jako najważniejszy, niesłusznie zakwestionowany przepis autorzy wskazywali ten, który stanowił, że o dostępie do archiwów IPN decyduje jego prezes. Uchylenie tego przepisu spowodowało bowiem zamknięcie archiwów dla dziennikarzy i historyków. Kolejnym argumentem pojawiającym się w Rz było przekonanie, że sędziowie wydający wyrok byli stronniczy, przekroczyli swoje kompetencje i zamiast orzekać o konstytucyjności przepisów, wyrokowali, czym i jaka powinna być lustracja. I właśnie krytyka sędziów z jednej strony, a opisywanie nowych pomysłów na przeprowadzenie lustracji oraz „naprawienie” TK z drugiej, pozwoliły publikacjom Rz zachować prolustracyjny charakter.

Odpowiedzi, jakie uzyskano na ostatnie pytanie badawcze, nie byłyby zrozumiałe i potwierdzone, gdyby nie przebieg wcześniejszych etapów analizy. Jak wykazało badanie, prezentowane w publikacjach obu dzienników poglądy dotyczące lustracji miały decydujący wpływ na stanowisko, jakie dziennikarze gazet zajęli wobec wyroku TK. Analiza treści artykułów pokazała, że autorzy piszący na łamach Rz zajęli krytyczne stanowisko wobec orzeczenia TK, natomiast w GW pisano o nim pozytywnie. Interesujące wnioski nasuwają się przy analizie artykułów publikowanych w Rz. Gazeta już przy ocenie ustawy lustracyjnej ujawniła niejednoznaczne poglądy na temat konstytucyjności jej przepisów. Prawdopodobnie redakcja wahała się odnośnie kwestii, jak zachować w tej sytuacji stanowisko prolustracyjne, a raczej: jak,

${ }^{36}$ Analizując argumenty, jakie padły w obu gazetach w ocenie lustracji i wyroku TK, słuszne wydaje się stwierdzenie P. Śpiewaka, że spór o lustrację rozszerzono w Polsce do poważnego sporu światopoglądowego: „W kontekście debat rozliczeniowych dyskutowano niemal o wszystkim: o państwie prawa, o jakości demokracji, o prawach jednostki, o zakresie prywatności, o korupcji i szantażu, o zdradzie narodowej, o jakości i powadze polskiego liberalizmu, o winie i przebaczeniu. Dlatego ten spór wydaje się tak rozległy i intelektualnie doniosły”. P. Śpiewak, Problem..., op. cit., s. 220. 
krytykując ustawę i chwaląc wyrok TK, nie sprawić wrażenia, że dziennik występuje przeciwko lustracji. Trzeba bowiem pamiętać, że gazety mają swoich stałych odbiorców (czytelników), którzy są przyzwyczajeni i oczekują od autorów zajmowania określonego stanowiska ${ }^{37}$. Analizując postawę redakcji Rz, warto połączyć prezentowane przez jej dziennikarzy poglądy dotyczące wyroku TK z sytuacją, jaka zaistniała w polskim życiu politycznym tuż przed i w trakcie rozpatrywania przez TK konstytucyjności zapisów ustawy lustracyjnej. Otóż środowisko związane z PiS (zdając sobie najprawdopodobniej sprawę, że część ustawy jest sprzeczna z Konstytucją, a także chcąc opóźnić orzeczenie TK) podjęło próbę podważenia bezstronności sędziów TK. Dzięki takiemu działaniu z jednej strony, odciągano uwagę od meritum proble$\mathrm{mu}, \mathrm{z}$ drugiej, osłabiano i podważano orzeczenie TK. Dziennikarze Rz również podjęli ten trop i zajęli negatywne stanowisko wobec wyroku, skupiając się głównie na kontrowersjach wokół sędziów. Dzięki temu Rz zachowała i broniła prolustracyjną linię publikowanych treści. Redakcja GW znalazła się tu w wygodniejszej sytuacji, ponieważ wyrok TK pokrywał się z wcześniej prezentowanymi na łamach poglądami na temat lustracji. W publikacjach po orzeczeniu sędziów znaleziono jednak jedną cechę wspólną obu gazet. Zarówno dziennikarze GW, jak i Rz, opisywali nowe propozycje przeprowadzenia w Polsce lustracji. Różnie je jednak komentowali, co znów miało ścisły związek z linią programową redakcji.

\section{WNIOSKI}

PRZEd PRZYSTĄPIENIEM DO ANALIZY ZA£OŻono, że media mają określone tendencje polityczne, co ma zasadniczy wpływ na treść i formę przekazu prasowego. Szczegółowa analiza artykułów prasowych GW i Rz potwierdziła postawioną wcześniej hipotezę - autorzy publikacji zamieszczanych w obu gazetach komentowali wyrok w sposób stronniczy i opozycyjny względem siebie. Powodem była prezentowana przez redakcje różna linia programowa, a co za tym idzie: odmienny stosunek do lustracji. W toku analizy stwierdzono, że dziennikarze GW

${ }^{37}$ Już w 1974 r. trzej badacze Elihu Katz, Jay G. Blumler i Michael Gurevitch w założeniach dotyczących aktywności odbiorczej stwierdzili, że „odbiorcy mediów to jednostki i zbiorowości (audytoria, publiczności) aktywne, które użytkują media w sposób celowy, dążąc do osiągnięcia określonych korzyści. Zdarzają się oczywiście przypadkowe kontakty z mediami, jednak na ogół odbiorcy użytkują media według wzorców ukształtowanych pod wpływem mniej lub bardziej sprecyzowanych oczekiwań”. Zob. M. Mrozowski, Media..., op. cit., s. 364 . 
byli przeciwni lustracji, a ci piszący na łamach Rz opowiadali się za. Zgodnie z tą tendencją obie gazety formułowały przekaz.

Wyniki przeprowadzonej analizy można odnieść do teorii argumentacji Chaima Perelmana, który zakładał (ujmując skrótowo), że celem argumentacji nie jest wyprowadzanie wniosków z przesłanek, lecz wywołanie lub wzmocnienie poparcia audytorium dla prezentowanych mu tez. Ch. Perelman uważal, że mówca powinien wychodzić tylko od tych przesłanek, które są aprobowane przez słuchaczy. Jeśli tak nie jest, mówca musi wzmocnić przychylność audytorium wszystkimi możliwymi środkami. Według Ch. Perelmana, w argumentacji nie istnieje zapewniony na stałe status prawdy. Każdy fakt, każdą prawdę najlepiej podważyć, zestawiając z innymi faktami lub prawdami ${ }^{38}$. Ta koncepcja znajduje potwierdzenie w przeprowadzonej na potrzeby artykułu analizie. Zarówno autorzy publikacji GW, jak i Rz, w artykułach dotyczących ustawy lustracyjnej, rozprawy przed TK i samego wyroku, przedstawiali takie argumenty i przykłady, które potwierdzały słuszność ich stanowiska. Nawet jeśli autor tekstu nie wyrażał swoich poglądów wprost, zazwyczaj starał się tak dobrać przedstawiane fakty i cytowane wypowiedzi, by treść artykułu wpisywała się w przedstawiany na łamach światopogląd redakcji. W formach, w których taka odautorska selekcja i manipulacja jest ograniczona (np. w wywiadach), gazety pozostawały przy publikacji treści zgodnych z ich linią programową. W przypadkach, w których możliwy jest komentarz, pojawiały się także zdania przeciwne.

Należy stwierdzić, że opisywanie przez dziennikarzy GW i Rz problemu lustracji przed i po wyroku TK miało swój ciąg logiczny. Raz określone stanowisko było konsekwentnie podtrzymywane. A z tego wynikał konkretny dobór i selekcja publikowanych treści. Należałoby jednak przyjąć, że takie z reguły stronnicze działania redakcji dzienników nie były wyrazem złej woli czy zakłamania, ale wynikały z prawdziwego przekonania o słuszności stawianych tez. Gazety musiały umiejętnie dopasować się do zmieniającej się sytuacji politycznej. I czyniły to skutecznie, pozostając w zgodzie z własną linią programową, zachowując wiarygodność w oczach czytelników.

${ }^{38} \mathrm{Ch}$. Perelman, Imperium retoryki, Warszawa 2004, s. 22-46. 
ZAŁĄCZNIK. BIBLIOGRAFIA ARTYKUŁÓW PRASOWYCH.

$$
\text { „Gazeta Wyborcza” }
$$

Anderman J., Bagnet na broń, „Gazeta Wyborcza” z dnia 7 maja 2007.

Bachmann K., Lustracja - powtórka z lat 6o., „Gazeta Wyborcza” z dnia 8 maja 2007.

BART, Ta ustawa obraża społeczeństwo, „Gazeta Wyborcza” z dnia 4 maja 2007.

Beylin M., „Świąteczna” wedtug Beylina, „Gazeta Wyborcza” z dnia 12 maja 2007.

Bikont A., Szczęsna J., Oddychając kurzem, „Gazeta Wyborcza” z dnia 7 maja 2007.

Blumsztajn S., Sobota prasujaca, „Gazeta Wyborcza” z dnia 12 maja 2007.

Bojanowski M., Lustracja omija gospodarkę, „Gazeta Wyborcza” $\mathrm{z}$ dnia 14 maja 2007.

Bosacki M., Premier i stu agentów, „Gazeta Wyborcza” z dnia 15 maja 2007.

Bosacki M., Przegląd prasy. Co dalej z lustracja, „Gazeta Wyborcza” z dnia 15 maja 2007.

Czech M., Dobry dzień dla państwa, „Gazeta Wyborcza” z dnia 10 maja 2007.

Czech M., Nigdy niekończąca się dezubekizacja, „Gazeta Wyborcza” z dnia 10 maja 2007.

Czech M., Trybunat obronit demokrację, „Gazeta Wyborcza” z dnia 12 maja 2007.

Czech M., Siedlecka E., Będzie wyrok na lustrację, „Gazeta Wyborcza" z dnia 10 maja 2007.

Czuchnowski W., Zlustrować gajowego Maruchę (dobrowolnie), „Gazeta Wyborcza” z dnia 9 maja 2007.

Czuchnowski W., Kurski J., PAP, Wroński P., Lustracja to nie zemsta, „Gazeta Wyborcza” z dnia 12 maja 2007.

Czuchnowski W., Siedlecka E., Czy pan to sprawdzit, panie pośle Mularczyk?, „Gazeta Wyborcza” z dnia 11 maja 2007.

Głuchowski P., Jest miejsce na nowy centrolew, „Gazeta Wyborcza” z dnia 12 maja 2007.

Kalukin R., Stracona szansa na lustrację, „Gazeta Wyborcza” $\mathrm{z}$ dnia 7 maja 2007. 
KID, Gwiazda oskarża Borusewicza. Fragment stenogramu posiedzenia Senatu 10 maja 2007r., „Gazeta Wyborcza” z dnia 12 maja 2007.

KNYSZ, Kapituła Orła Białego bez Bartoszewskiego?, „Gazeta Wyborcza" z dnia 5 maja 2007.

KNYSZ, Kiedy wyrok w Dzienniku Ustaw?, „Gazeta Wyborcza” z dnia 14 maja 2007.

KNYSZ, Siedlecka E., W, Noc dwóch teczek, „Gazeta Wyborcza” z dnia 11 maja 2007.

Kolenda-Zaleska K., Monte Christo po polsku, „Gazeta Wyborcza” $\mathrm{z}$ dnia 7 maja 2007.

Krzyk J., Plan remontów? Też zlustrujemy, „Gazeta Wyborcza” z dnia 10 maja 2007.

Kublik A., Operacja „Trybunat”, „Gazeta Wyborcza” z dnia 11 maja 2007.

Kublik A., Prawo $w$ kolejce do druku, „Gazeta Wyborcza” z dnia 15 maja 2007.

Kurski J., Rubikon przekroczony, „Gazeta Wyborcza” z dnia 11 maja 2007.

Kurski J., To problem braci Kaczyńskich, „Gazeta Wyborcza” $\mathrm{z}$ dnia 12 maja 2007.

Leszczyński A., O uczciwości zamiast o kompetencjach, „Gazeta Wyborcza" z dnia 11 maja 2007.

Lis T., Reduta Stępnia, „Gazeta Wyborcza” z dnia 14 maja 2007.

Lustracja bez jadu - komentarze do wyroku Trybunatu, „Gazeta Wyborcza" z dnia 12 maja 2007.

Machcewicz P., Jawne archiwum - wygodna fikcja, „Gazeta Wyborcza" z dnia 17 maja 2007.

Medek J., Szacki W., Próbują wskrzesić lustrację, „Gazeta Wyborcza” z dnia 15 maja 2007.

Michnik A., Otwórzmy teczki, „Gazeta Wyborcza” z dnia 14 maja 2007.

Michnik A., Sukces $i$ strach, „Gazeta Wyborcza” z dnia 12 maja 2007.

ML, Wczoraj przeczytane. Premier Jarosław Kaczyński $w$ wywiadzie dla „Rzeczpospolitej”, „Gazeta Wyborcza” z dnia 14 maja 2007.

Nowakowska A., Prof. Zoll: Groźna władza większości, „Gazeta Wyborcza" z dnia 12 maja 2007. 
Ola, Wiśniewska K., Czy IPN utrudnia pracę Kościołowi, „Gazeta Wyborcza" z dnia 4 maja 2007.

Olejnik M., Lustracyjny policzek, „Gazeta Wyborcza” z dnia 14 maja 2007.

Pacewicz P., Wojciechowski M., Trybunat obronit Polskę, „Gazeta Wyborcza” z dnia 14 maja 2007.

PAP, UE. Socjaliści o polskiej lustracji, „Gazeta Wyborcza” z dnia 4 maja 2007.

PAP, PW, RPO pyta Dorna o posła PiS Mularczyka, „Gazeta Wyborcza" z dnia 17 maja 2007.

Premier Jarosław Kaczyński: Lista agentów do konstytucji, „Gazeta Wyborcza” z dnia 14 maja 2007.

Siedlecka E., Co IPN ma zrobić z oświadczeniem premiera?, „Gazeta Wyborcza" z dnia 14 maja 2007.

Siedlecka E., Dorn do TK: Wstrzymać sąd nad lustracja, „Gazeta Wyborcza” z dnia 8 maja 2007.

Siedlecka E., Dziewięć godzin z lustracją przed Trybunałem, „Gazeta Wyborcza" z dnia 10 maja 2007.

Siedlecka E., I jak tu się, człowieku, zlustrować, „Gazeta Wyborcza" z dnia 15 maja 2007.

Siedlecka E., Muszq oddać oświadczenia lustracyjne, „Gazeta Wyborcza” z dnia 12 maja 2007.

Siedlecka E., Startuje maraton lustracyjny, „Gazeta Wyborcza” z dnia 9 maja 2007.

Siedlecka E., Trybunat nie obalit lustracji, „Gazeta Wyborcza” z dnia 14 maja 2007.

Smoleński P., U nas sq̨du nie będzie. Reportaż. Lustracja na wyższych uczelniach, „Gazeta Wyborcza” z dnia 5 maja 2007.

Starczewska K., Nie ulegnę przymusowi, „Gazeta Wyborcza” z dnia 9 maja 2007.

Stasiński P., Nie otwierać teczek, bronić ludzi, „Gazeta Wyborcza” $\mathrm{z}$ dnia 15 maja 2007.

Stępień J., Jaka lustracja. Uzasadnienie wyroku Trybunału Konstytucyjnego, „Gazeta Wyborcza” z dnia 12 maja 2007.

Szacki W., Prawo i Sprawiedliwość chce przyciąć emerytury esbekom, „Gazeta Wyborcza” z dnia 5 maja 2007.

Uhlig D., Dorn: Prof. Geremek nie znat prawa, „Gazeta Wyborcza" z dnia 9 maja 2007.

Uhlig D., Lustrowanie konstytucja, „Gazeta Wyborcza” z dnia 14 maja 2007. 
Uhlig D., Wroński P., I co dalej z lustracją?, „Gazeta Wyborcza” z dnia 16 maja 2007.

Wroński P., Konstytucja 3 maja z lustracją w tle, „Gazeta Wyborcza” z dnia 4 maja 2007.

Wroński P., Lustrujemy Konstytucję 3 maja, „Gazeta Wyborcza” z dnia 4 maja 2007.

Wroński P., Załuski W., Razem prezydenci i obywatele, „Gazeta Wyborcza" z dnia 18 maja 2007.

Wyrok Trybunatu $w$ sprawie lustracji, „Gazeta Wyborcza” z dnia 14 maja 2007.

Żakowski J., Dużo więcej niż lustracja, „Gazeta Wyborcza” z dnia 14 maja 2007.

\section{„RZECZPOSPOLITA"}

Andrzejewski J. Ł. P, Lustracja $w$ imię konstytucji to powszechny dostęp do teczek, „Rzeczpospolita” z dnia 7 maja 2007.

AS, MJ, Straszyli Geremka, o Jałowieckim zapomnieli, „Rzeczpospolita” z dnia 14 maja 2007.

Baronowska K., Historycy o zamkniętych przez Trybunał archiwach, „Rzeczpospolita” z dnia 14 maja 2007.

BW, EO, JS, MK, Lustracyjny chaos: wydawcy stosuja się do przepisów, naukowcy czekaja, „Rzeczpospolita” z dnia 15 maja 2007.

BW, EO, MJ, Naprawianie Trybunału Konstytucyjnego, „Rzeczpospolita" z dnia 14 maja 2007.

Gardocki L., I cóż, że o lustracji, „Rzeczpospolita” z dnia 17 maja 2007.

Gardynik A., Jałoszewski M., Dorn: Trybunał niech poczeka, „Rzeczpospolita” z dnia 8 maja 2007.

Gardynik A., Kałucki J., Południk E., Wjaki sposób otworzyć archiwa, „Rzeczpospolita” z dnia 14 maja 2007.

Gardynik A., Olczyk E., Dwóch sędziów wykluczonych, „Rzeczpospolita" z dnia 11 maja 2007.

Gardynik A., Olczyk E., Dziś sądny dzień dla lustracji, „Rzeczpospolita" z dnia 9 maja 2007.

Gardynik A., Olczyk E., PiS kontra Trybunat, „Rzeczpospolita” $\mathrm{z}$ dnia 11 maja 2007.

Gardynik A., Olczyk E., Sopińska A., Trybunał obalit część spornych przepisów, „Rzeczpospolita” z dnia 12 maja 2007. 
Gardynik A., Olczyk E., Wildstein B., Wyrok Trybunatu w tym tygodniu, „Rzeczpospolita” z dnia 10 maja 2007.

Gardynik A., Waszkielewicz B., Trybunat sq̨dzi lustrację, „Rzeczpospolita" z dnia 10 maja 2007.

Gottesman K., Esbecy nie będa już anonimowi, „Rzeczpospolita” z dnia 9 maja 2007.

Gottesman K., Nie pozwólmy zlikwidować IPN, „Rzeczpospolita” z dnia 14 maja 2007.

Jałoszewski M., Kochanowski: otworzyć teczki, „Rzeczpospolita” z dnia 17 maja 2007.

Jałoszewski M., Jendroszczyk P., Niewiadomski A., Czeskie akta otwarte dla Polaków, „Rzeczpospolita” z dnia 15 maja 2007.

Janke I., Dobra decyzja Jerzego Stępnia, „Rzeczpospolita” z dnia 11 maja 2007.

Janke I., Lichocka J., Powróćcie do swojego etosu, „Rzeczpospolita" z dnia 12 maja 2007.

Jendroszczyk P., Agent doradca rządu, „Rzeczpospolita” z dnia 7 maja 2007.

Jendroszczyk P., Pozorne rozliczenie z NRD-owska przeszłościa, „Rzeczpospolita” z dnia 10 maja 2007.

KW, Nowe dokumenty z lat 70., „Rzeczpospolita” z dnia 11 maja 2007.

Lichocka J., Infamia dla prawdziwych agentów, „Rzeczpospolita" z dnia 14 maja 2007.

Lisicki P., Zagrożona polska demokracja, „Rzeczpospolita” z dnia 12 maja 2007.

MJ, ŻS, Jak się teraz lustrować, „Rzeczpospolita” z dnia 12 maja 2007.

NP, Zieliński A. M., Czas na tych, którzy werbowali, „Rzeczpospolita” z dnia 5 maja 2007.

Olczyk E., Lustracyjny szczyt u prezydenta, „Rzeczpospolita” z dnia 16 maja 2007.

Olczyk E., Polityków pomyst na lustrację, „Rzeczpospolita” z dnia 16 maja 2007.

Olczyk E., Trybunat: ustawa lustracyjna częściowo niezgodna z konstytucja, „Rzeczpospolita” z dnia 12 maja 2007.

Olczyk E., Żadnych oświadczeń, teczki do Internetu, „Rzeczpospolita” z dnia 10 maja 2007.

Olczyk E., Waszkielewicz B., Ostry spór polityków o rolę Trybunatu, „Rzeczpospolita” z dnia 14 maja 2007. 
Pałka P., Przychodzi esbek do Lwa Rywina, „Rzeczpospolita” z dnia 17 maja 2007.

Pałka P., Sędziowie we własnej sprawie, „Rzeczpospolita” z dnia 11 maja 2007.

PAP, Zieliński A. M., Byli esbecy bez przywilejów, „Rzeczpospolita" z dnia 5 maja 2007.

Praczyk G., Kapituła się kurczy, „Rzeczpospolita” z dnia 8 maja 2007.

Romaszewska A., Ratujmy z lustracji, co się da, „Rzeczpospolita” z dnia 16 maja 2007.

Rybińska A., Wildstein wywotuje trzęsienie ziemi, „Rzeczpospolita" z dnia 16 maja 2007.

Sadecki J., Ujawnić teczki, ale bez spraw osobistych, „Rzeczpospolita" z dnia 4 maja 2007.

Safjan M., Trybunat Konstytucyjny nie jest trzecia izba parlamentu, „Rzeczpospolita” z dnia 14 maja 2007.

Semprich Ż., „Rz” radzi: jak się teraz zlustrować?, „Rzeczpospolita" z dnia 15 maja 2007.

Semka P., Autorytet i wiarygodność Trybunału, „Rzeczpospolita” z dnia 10 maja 2007.

Semka P., Dziwna przemiana Adama Michnika, „Rzeczpospolita” $\mathrm{z}$ dnia 15 maja 2007.

Semka P., Podcięte PiS, triumfująca lewica i niewidoczna PO, „Rzeczpospolita” z dnia 12 maja 2007.

Semka P., Polityka puka do bram Trybunatu, „Rzeczpospolita” z dnia 11 maja 2007.

Sopińska A., Czy teczki ujrza światło dzienne?, „Rzeczpospolita” z dnia 12 maja 2007.

Sopińska A., Historyk o ostrym spojrzeniu, „Rzeczpospolita” z dnia 12 maja 2007.

Sopińska A., Trybunat zamknąt teczki, „Rzeczpospolita” z dnia 14 maja 2007.

Subotić M., Dwie drogi do lustracji, „Rzeczpospolita” z dnia 14 maja 2007.

Subotić M., Nie wpisywać lustracji do konstytucji, „Rzeczpospolita" z dnia 18 maja 2007.

Terlikowski P. T., Otwarcie archiwów, czyli różne słów znaczenia, „Rzeczpospolita” z dnia 17 maja 2007.

Terlikowski P. T., Wszechwładne państwo Kaczyńskich, „Rzeczpospolita" z dnia 16 maja 2007. 
Wildstein B., Demokracja wedtug europejskiego salonu, „Rzeczpospolita" z dnia 7 maja 2007.

Wildstein B., Ozdrowieńczy wstrząs jawności, „Rzeczpospolita” $\mathrm{z}$ dnia 12 maja 2007.

Wildstein B., Pantomima Tomaszewskiego, czyli artysta pod presją aparatu bezpieczeństwa, „Rzeczpospolita” z dnia 10 maja 2007.

Wildstein B., Prostoduszność i elegancja, „Rzeczpospolita” z dnia 15 maja 2007.

Wildstein B., Zwycięstwo antylustracyjnego frontu, „Rzeczpospolita" z dnia 14 maja 2007.

Winczorek P., Jeśli się chce, to można, „Rzeczpospolita” z dnia 16 maja 2007.

Winczorek P., Sędziowie podejrzani - ale o co?, „Rzeczpospolita” z dnia 11 maja 2007.

Ziemkiewicz A. R., Ewangelicy trybunalscy, „Rzeczpospolita” z dnia 18 maja 2007.

Ziemkiewicz A. R., Wiarygodność i bezstronność, „Rzeczpospolita” z dnia 11 maja 2007.

Żakowski J., Nasze cierpienia $w$ lustracyjnym piekle, „Rzeczpospolita” z dnia 18 maja 2007.

\section{SUMMARY}

THE ARTICLE deals with a problem of vetting in the press discourse taken "Gazeta Wyborcza" and "Rzeczpospolita" as an example. There is an attempt to present oppositional attitudes of both titles against each other. All the articles about a vetting problem a week before and after May 11, 2007 were analyzed. Some questions had also been asked. Was the sentence similarly commented by both newspapers and Why was it commented in a particular way? After the analysis, the hypothesis was confirmed. That is, the comments on the sentence were opposite and unbalanced. It was because of different newspapers' programme lines. It was ascertained that "Gazeta Wyborcza" was against the vetting whereas "Rzeczpospolita" supported it.

\section{NOTA O AUTORCE}

Paulina Jęczmionka [pjeczmionka@gmail.com] - studentka I roku studiów II stopnia na Wydziale Nauk Politycznych i Dziennikarstwa UAM, kierunek: politologia, specjalność: reklama i promocja. Tytuł 
„Gazeta Wyborcza” $i$ „Rzeczpospolita” wobec wyroku Trybunatu Konstytucyjnego...

licencjata politologii (specjalność: dziennikarstwo) uzyskała w 2010 roku. Interesuje się problematyką mediów masowych, komunikowania politycznego, teorią dziennikarstwa oraz językiem mediów i ich rolą w kształtowaniu świadomości politycznej. 